Principle 25: Peace, development, and environmental protection, are interdependent and indivisible.

Principle 26: States shall resolve all their environmental disputes peacefully and by appropriate means in accordance with the Charter of the United Nations.
Principle 27: States and people shall cooperate in good faith and in a spirit of partnership in the fulfillment of the principles embodied in this Declaration, and in the further development of international law in the field of sustainable development.

\title{
Earthwatch Europe
}

$\mathrm{O}$ ver the last thirty years, there has been increasing awareness that the Earth* really matters, and that species, habitats, and even the whole planet,* are at risk from human-induced change. Paradoxically, over the same period, funding for science has been in steady decline especially for environmental sciences. 'The field sciences have become the Cinderella of the sciences, due to decisions taken in the 1950 s which led to the bulk of science funding going to medicine, physical sciences such as nuclear power, and space research. It was believed that part of the job of the field scientist could be done from orbiting satellites, but we now know that without an army of foot-soldiers to "ground truth" the images produced, they are vulnerable to misinterpretation'.

The concept of Earthwatch was born in 1971 in Boston, Massachusetts, with a group of Harvard and MIT academics. Their question was: with governmental and institutional funding declining, where could future human and financial resources be found for field research and implementation? Their answer was simple - Earthwatch volunteers would pay for the projects on which they would work. To a public demanding more than mere waving of a banner, or writing a cheque to help to solve environmental problems, Earthwatch offers practical involvement in a way which generates millions of pounds or dollars to finance field research and due implementation of its findings.

\section{Enlightened Volunteers Welcome}

Earthwatch volunteers need no special skills or attributes other than a willingness to share the costs and labour of field research with commitment, curiosity, a reasonable degree of work-rigour, and a lively sense of humour. But can volunteers be of value to scientists in the field? Much basic field-work requires simple, often repetitive, data-gathering techniques which can easily be taught in the field. Far from being a burden, many scientists find themselves enjoyably stretched and challenged by the talents and opinions offered by the public.

The human and financial resources that Earthwatch can generate are limited only by the numbers and qualities of people it can mobilize. To date, 28,000 volunteers have served in the Earth Corps, contributing over $£ 10$ million to field research. The potential for mobilizing a similar resource among Europe's 350 million inhabitants should be at least as good. Earthwatch Europe, now chaired by Sir Crispin Tickell (formerly British Ambassador to the United Nations in New York and currently Warden of Green College, Oxford), has an office in Oxford through which field researchers in all parts of Europe have access to the $£ 1.3$ million in grants and 300,000 hours of labour which Earthwatch supplies annually.

* Really meaning The Biosphere, as we have striven to clarify for many years past, and plan to continue to emphasize world-wide. Ed.
Research scientists can apply to the Oxford office for support as to any other grant-giving body. Basic, applied, and interdisciplinary, research projects in the Earth, Life, and Human, sciences are considered; grants range from $£ 5,000$ to $£ 50,000$ and above. The research must be labourintensive to qualify, and be post-doctoral or equivalently enlightened field research of high scientific merit. After a decision, based on a preliminary proposal, that the project appears to be suitable, a full proposal is invited and this goes through a rigorous peer-review system.

\section{Board of Science Advisers}

Guidance on which areas of research should be supported is provided by a prestigious Board of Science Advisors, chaired by Professor Sir Richard Southwood, FRS, Warden of Merton College, Oxford. Scientists from anywhere in Europe, both East and West, and from developing countries, can apply for support for projects anywhere in the world. Collaboration between groups in more than one country is welcomed - for example, a project on restoration of landscapes after mining is running simultaneously in Wales and Bulgaria.

Volunteers, who must be or become members of Earthwatch, choose which projects they wish to join from descriptions in a two-monthly magazine. They enrol for two to four weeks and pay between $£ 450$ and $£ 1,200$ towards the costs of the projects. The value of their participation to science is an expanded range of results, while to society, it offers a growing group of betterinformed and enthusiastic people who can influence the way others think and act. Scientific literacy within the community is enhanced through Earthwatch participation. Earthwatch sponsors Education Awards to enable teachers and students to gain practical experience. Industry increasingly looks to Earthwatch as a training ground through which to encourage environmental good practice among its employees and, ultimately, employers. Small groups of members and volunteers are now to be found in Switzerland, The Netherlands, Germany, Italy, Spain, Sweden, and elswhere.

More than 3,500 people take part in Earthwatch projects each year, and more than a third of them return for more! Scientists also get the Earthwatch habit; some have received regular support for more than a decade. Earthwatch appeals to the spirit of adventure and discovery. It can change people's lives and the public's attitude to our environment. Further details may be obtained from the undersigned:

BRIAN W. WALKer, Director

Earthwatch Europe

Belsyre Court

57 Woodstock Road

Oxford OX2 $6 \mathrm{HU}$

England, $U K$.

Tel. (44 865) 311600

Fax: (44 865) 311383 